\title{
Eliza Chilimoniuk-Przeździecka
}

Szkoła Główna Handlowa w Warszawie

e-mail: eliza.przezdziecka@sgh.waw.pl

\section{OFFSHORING PROCESÓW OPARTYCH NA WIEDZY - ANALIZA EKSPORTU USEUG}

\section{OFFSHORING OF KNOWLEDGE-INTENSIVE PROCESSES - ANALYSIS OF SERVICES EXPORT}

DOI: $10.15611 /$ pn.2017.498.03

JEL Classification: F12, F14, F23.

Streszczenie: W niniejszym artykule poddaje się analizie wybrane czynniki dotyczące potencjału innowacyjnego gospodarki, zasobów, kosztów i wydajności siły roboczej oraz inwestycji w B+R. Na tej podstawie podjęto próbę oceny zależności między tymi czynnikami a eksportem usług opartych na wiedzy, a także eksportem wyróżnionej przez Autorkę grupy usług nazwanych jako biznesowe usługi oparte na wiedzy. Usługi te uznano za przejaw dokonywania przez przedsiębiorstwa offshoringu procesów pozaprodukcyjnych, czyli zlecania wykonania tych procesów zagranicznym wykonawcom. Przeprowadzone badanie empiryczne pozwoliło zidentyfikować czynniki najsilniej wpływające na eksport biznesowych uslug opartych na wiedzy, a tym samym sprzyjające poprawie atrakcyjności kraju jako miejsca lokalizacji procesów wiedzochłonnych w ramach offshoringu.

Słowa kluczowe: usługi biznesowe, offshoring, eksport usług.

Summary: This article analyzes selected factors regarding the potential of innovative economy, resources, costs and productivity of the workforce as well as investments in R\&D. On this basis, an attempt was made to assess the relationship between these factors and the export of knowledge-based services, as well as the export of a group of services named as business services based on knowledge distinguished by the author. These services were considered as a sign of off-shoring of non-production processes. The empirical study made it possible to identify the factors that highly affect the country's share in international supply networks, i.e. conducive to improve the attractiveness of the economy as a place for locating knowledge-intensive processes as part of offshoring.

Keywords: business services, offshoring, export of services. 


\section{Wstęp}

Umiędzynarodowienie procesów tworzących łańcuch wartości w ramach offshoringu pierwszej generacji dotyczyło wyłącznie procesów produkcyjnych. Produkcja dóbr pośrednich odbywała się zazwyczaj w niezależnych przedsiębiorstwach produkcyjnych i dotyczyła m.in. takich branż, jak branża tekstylna, odzieżowa, maszynowa, samochodowa, urządzeń elektronicznych. Dostawy do gospodarek wysoko rozwiniętych realizowano z krajów o niskich kosztach siły roboczej. Od połowy lat siedemdziesiątych do połowy lat dziewięćdziesiątych amerykańskie przedsiębiorstwa podwoiły wartość importu komponentów do produkcji przemysłowej [Campa, Goldberg 1997; Lewin, Zhong 2012]. Na bazie tych doświadczeń przedsiębiorstwa zaczęły poszukiwać nowych możliwości w zakresie obniżania kosztów działalności gospodarczej w sferze pozaprodukcyjnej. Przedsiębiorstwa coraz aktywniej zaczęły uczestniczyć w międzynarodowych sieciach dostaw, realizując offshoring drugiej generacji, czyli zlecanie wykonawcom zagranicznym procesów pozaprodukcyjnych. Przedmiotem tej współpracy stały się usługi biznesowe, czyli świadczenia związane z prowadzeniem działalności gospodarczej i obsługą przedsiębiorstw [GUS 2016; Chilimoniuk-Przeździecka 2011].

W niniejszym artykule przedstawione będą usługi biznesowe, które charakteryzują się znacznymi nakładami wiedzy (knowledge-intensive business services KIBS). Można je również nazwać wiedzochłonnymi usługami biznesowymi lub usługami biznesowymi opartymi na wiedzy'.

Szczegółową analizę usług biznesowych opartych na wiedzy przeprowadził Miles i in. [1995], wyróżniając ich główne cechy oraz definiując jako „usługi, które wiążą się z działalnością gospodarczą, której celem jest kreowanie, gromadzenie lub upowszechnianie wiedzy" [Miles i in. 1995, s. 18].

Inspirację do podjęcia badania zagadnień związanych z offshoringiem procesów pozaprodukcyjnych stanowił obserwowany w ostatnim czasie wzrost znaczenia usług w handlu międzynarodowym, a w szczególności usług związanych z międzynarodową współpracą przedsiębiorstw. Celem artykułu jest zidentyfikowanie czynników wpływających na handel usługami biznesowymi opartymi na wiedzy. Cel ten zostanie osiągnięty dzięki przedstawieniu miejsca opisywanych usług w między-

${ }^{1}$ Klasyfikacja Eurostatu, zgodnie z którą sektory wysokich technologii obejmują sektory wytwórcze i usługi intensywnie korzystające $\mathrm{z}$ wiedzy, usługi zaawansowane technologicznie, porządkuje na podstawie intensywności technologicznej (wg klasyfikacji działalności NACE). W przypadku gałęzi produkcyjnych rozróżnienia między wysoko, średniowysoko, średnionisko i nisko zaawansowanymi technologicznie gałęziami dokonuje się na podstawie określenia intensywności badań i rozwoju, czyli udziału wydatków na $\mathrm{B}+\mathrm{R}$ w kosztach działalności przedsiębiorstwa ogółem. Natomiast jeśli chodzi o usługi, wiedzochłonność ocenia się na podstawie odsetka pracowników z wyższym wykształceniem w ogóle zatrudnionych. Warto zauważyć, że statystyki dotyczące zatrudnienia w sektorach high-tech obejmują wszystkich zatrudnionych, w tym personel pomocniczy. Jest to prawdopodobnie przyczyną zawyżenia podawanej w statystykach liczby pracowników wysoko wykwalifikowanych. 
narodowych sieciach dostaw oraz zbadaniu czynników wpływających na eksport usług. Przeprowadzona analiza struktury geograficznej popytu i podaży, wynikająca z lokalizacji firm zlecających oraz wykonujących usługi, pozwoli zidentyfikować czynniki, dzięki którym dostawcy usług są konkurencyjni na rynku międzynarodowym. Wpływ tych czynników na eksport usług będzie zweryfikowany w modelach empirycznych. Tym samym zostaną określone najważniejsze czynniki kształtujące przewagi konkurencyjne kraju na światowym rynku usług wiedzochłonnych.

\section{Miejsce usług biznesowych w handlu międzynarodowym}

Ocena skali handlu usługami jest bardzo utrudniona. Wynika to nie tylko z różnorodności klasyfikacji usług. Wiele przeszkód wynika więc z faktu, że w analizie handlu usługami nie można zastosować warunku znanego z tradycyjnego sposobu analizy handlu międzynarodowego, czyli kryterium fizycznego przemieszczenia przedmiotu przez granicę [Budnikowski 2017], albowiem w przypadku wielu usług przemieszczenie to nie występuje lub jest trudne do zidentyfikowania. Wiele usług świadczonych jest na odległość i dostarczanych dzięki przesyłowi danych, np. przez Internet.

Zmiana charakteru usług na bardziej mobilne, trwałe i świadczone na odległość oraz serwicyzacja produkcji przemysłowej powodują, że są one coraz popularniejszym przedmiotem międzynarodowej wymiany, a ich udział w handlu międzynarodowym wzrasta. Sprzyja temu również gwałtowny rozwój technik informacyjnych i komunikacyjnych wpływających na wzrost handlowości usług, deregulacji branż usługowych, wcześniej kontrolowanych przez państwo, oraz procesów wielostronnej i regionalnej liberalizacji handlu usługami (szerzej np. w: [Kuźnar 2007]). Wartość światowego eksportu usług wzrosła z 395,6 mld USD w 1980 r. do 4879 mld USD w $2016 r^{2}$

Wzrostowi handlu usługami sprzyja upowszechnienie współpracy produkcyjnej przedsiębiorstw. Wydzielając procesy pozaprodukcyjne poprzez rozdzielenie elementów łańcucha wartości oraz zlecając ich wykonanie poza macierzystą organizacją, firmy uczestniczą w globalnych łańcuchach dostaw, kształtując w ten sposób nowy segment handlu usługami. Chodzi w tym przypadku o usługi świadczone przedsiębiorstwom przez inne przedsiębiorstwa, czyli usługi biznesowe.

W ostatnim czasie obserwujemy nadzwyczaj wysoką dynamikę światowego handlu usługami biznesowymi. Eksport usług biznesowych ogółem wzrósł w latach 2000-2014 prawie czterokrotnie. Przykładem największego wzrostu wartości handlu $\mathrm{w}$ analizowanej grupie usług są usługi informatyczne i informacyjne, których eksport światowy był w 2014 r. o 6,3-krotnie wyższy niż w 2000 r. Również w Polsce eksport usług informatycznych i informacyjnych rośnie bardzo szybko. Eksport ten

\footnotetext{
${ }^{2}$ Na podstawie bazy danych UNCTAD Stat, http://unctadstat.unctad.org/wds/TableViewer/tableView.aspx?ReportId=17648 (1.04.2018).
} 
był w 2013 r. ponad 48 razy wyższy niż w 2000 r. Eksport pozostałych usług biznesowych z Polski zwiększył się w tym czasie 9,4-krotnie33.

Rynek usług opartych na wiedzy zdominowany jest przez Stany Zjednoczone i Wielką Brytanię. Oba kraje dostarczały łącznie w 2004 r. ponad 46\% światowych usług opartych na wiedzy, a w 2016 r. ich łączny udział spadł do 34,26\%.

Porównując dane z 2004 r. i 2013 r., można zauważyć większe rozproszenie eksporterów. W 2004 r. było 10 krajów z ponadtrzyprocentowym udziałem w światowym eksporcie. Pozostałe kraje stanowiły wówczas 14\% światowego eksportu.

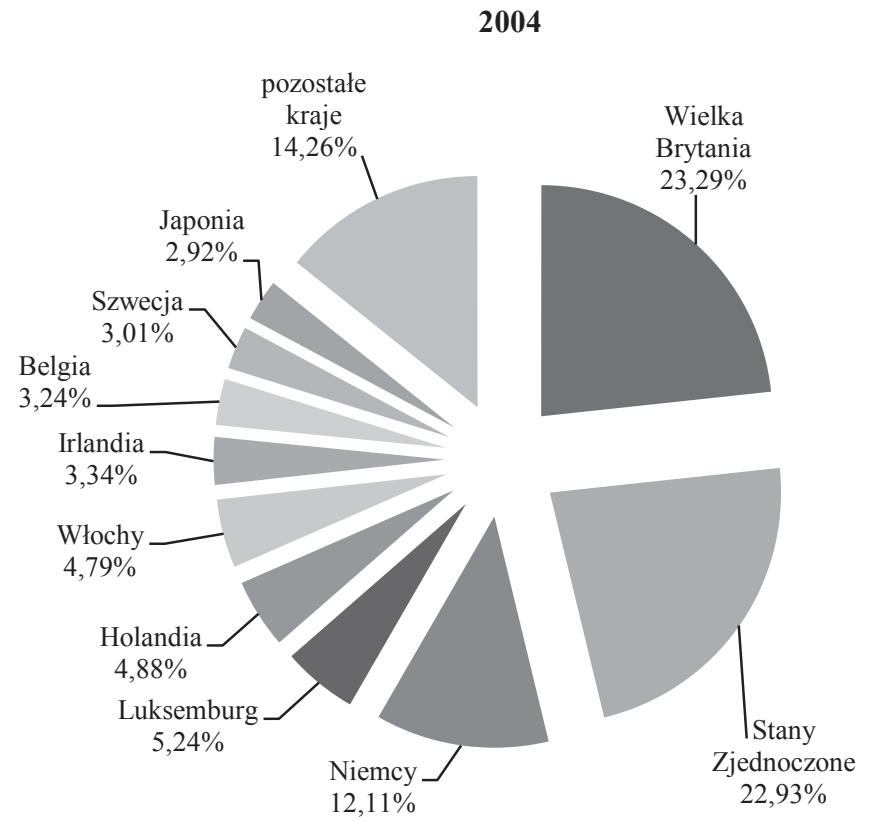

Rys. 1. Udział krajów w światowym eksporcie usług opartych na wiedzy w 2004 r. (w \%)

Źródło: opracowanie własne na podstawie danych Eurostatu oraz danych dla Indii: http://www.oecd-ilibrary.org/docserver/download/9259fd54-en.pdf?expires=1504121588\&id=id\&accname $=$ gu est\&checksum=C561608BCA9CD53F0CD07B4E62798445 (23.05.2017); danych dla Chin: http://www.chinadaily.com.cn/bizchina/2014-02/18/content_17289417.htm (23.05.2017).

Po ponad dekadzie na liście najważniejszych eksporterów mamy ponownie 10 państw z ponadtrzyprocentowym udziałem w światowym handlu. Jednak reszta świata dostarcza znacznie więcej niż w 2004 r., bo aż ponad jedną piątą światowego eksportu.

${ }^{3}$ Na podstawie danych WTO Statistics Database, Time series on international trade, http://stat. wto.org/StatisticalProgram/WSDBStatProgramHome.aspx?Language=E (12.04.2018). 
Warto także zauważyć, że Chiny i Indie, które pojawiły się na liście największych eksporterów analizowanych usług, wypracowały tę pozycję dzięki m.in. inwestycjom w badania i rozwój.

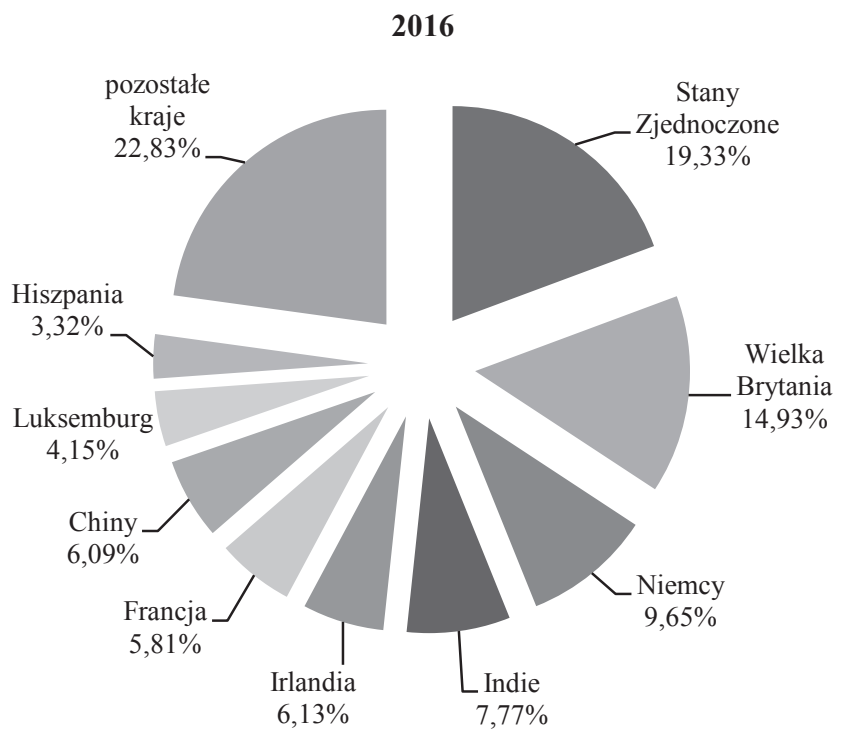

Rys. 2. Udział krajów w światowym eksporcie usług opartych na wiedzy w 2016 r. (w \%)

Źródło: opracowanie własne na podstawie danych Eurostatu oraz danych dla Indii: http://www.oecd-ilibrary.org/docserver/download/9259fd54-en.pdf?expires=1504121588\&id=id\&accname=gu est\&checksum=C561608BCA9CD53F0CD07B4E62798445 (23.05.2017); danych dla Chin: http://www.chinadaily.com.cn/bizchina/2014-02/18/content_17289417.htm (23.05.2017).

W 2014 r. Chiny wydały na badania i rozwój 2,05\% PKB. Wartość tego wskaźnika wzrastała w latach 2000-2014 średniorocznie o 5,6\%. W porównaniu z innymi krajami jest to wynik ponadprzeciętny (zob. tabela 1). Wyjątkowo niewielkie roczne zmiany wydatków na B+R w PKB dotyczyły Indii. W latach 2000-2011 wskaźnik ten wzrastał średniorocznie o niespełna $1 \%$ i nadal nie jest zbyt wysoki na tle innych gospodarek.

Wysokie wzrosty BERD odnotowano również w Chinach (7,97\%) oraz Indiach (7,57\%), lecz kraj ten nadal ma jedną z najniższych wartości wskaźnika BERD na świecie (zaledwie 0,29\%). Przyczyną tego są prawdopodobnie niskie wydatki na $\mathrm{B}+\mathrm{R}$ dokonywane przez przedsiębiorstwa krajowe. Wskaźnik BERD bowiem nie uwzględnia wydatków przedsiębiorstw zagranicznych, a te w przypadku Indii mogą mieć miejsce, ponieważ ciągle w tym kraju działa wiele filii przedsiębiorstw zagranicznych. Co prawda dane OECD (baza: Main Science and Technology Indicators) nie przedstawiają udziału firm zagranicznych w wydatkach na $\mathrm{B}+\mathrm{R}$ dokonywanych ze źródeł prywatnych, to jednak na podstawie struktury własności patentowej moż- 
Tabela 1. Wydatki na $\mathrm{B}+\mathrm{R}$ ogółem (GERD), wydatki na $\mathrm{B}+\mathrm{R}$ przedsiębiorstw (BERD) oraz średnia roczna stopa wzrostu w wybranych krajach

\begin{tabular}{|c|c|c|c|c|c|c|}
\hline Kraj & $\begin{array}{c}\text { GERD } \\
(\% \text { PKB) }\end{array}$ & & $\mathrm{GR}^{*}$ & $\begin{array}{c}\text { BERD } \\
(\% \text { PKB })\end{array}$ & & $\mathrm{GR} *$ \\
\hline Austria & 3,07 & $3,29 \%$ & $2000-2014$ & 2,17 & $3,84 \%$ & 2002-2014 \\
\hline Belgia & 2,47 & $1,69 \%$ & $2000-2014$ & 1,76 & $1,70 \%$ & $2000-2014$ \\
\hline Brazylia & 1,24 & $1,24 \%$ & $2000-2013$ & b.d. & b.d. & b.d. \\
\hline Chiny & 2,05 & $5,64 \%$ & $2000-2014$ & 1,58 & $7,97 \%$ & $2000-2014$ \\
\hline Czechy & 2,00 & $3,94 \%$ & $2000-2014$ & 1,12 & $3,74 \%$ & 2000-2014 \\
\hline Dania & 3,05 & $1,97 \%$ & 2001-2014 & 1,95 & $1,58 \%$ & 2001-2014 \\
\hline Egipt & 0,68 & $10,31 \%$ & $2000-2012$ & b.d. & b.d. & b.d. \\
\hline Estonia & 1,44 & $6,01 \%$ & $2000-2014$ & 0,63 & $11,34 \%$ & 2000-2014 \\
\hline Finlandia & 3,17 & $-0,17 \%$ & $2000-2014$ & 2,15 & $-0,48 \%$ & 2000-2014 \\
\hline Francja & 2,26 & $0,55 \%$ & $2000-2014$ & 1,46 & $0,83 \%$ & 2000-2014 \\
\hline Grecja & 0,84 & $2,94 \%$ & $2001-2014$ & 0,28 & $5,08 \%$ & $2000-2014$ \\
\hline Hiszpania & 1,23 & $2,26 \%$ & $2000-2014$ & 0,65 & $2,34 \%$ & 2000-2014 \\
\hline Holandia & 2,00 & $0,67 \%$ & 2000-2014 & 1,12 & $0,89 \%$ & 2000-2014 \\
\hline Indie & 0,81 & $0,99 \%$ & $2000-2011$ & 0,29 & $7,57 \%$ & $2000-2011$ \\
\hline Irlandia & 1,49 & $2,11 \%$ & $2000-2014$ & 1,11 & $2,55 \%$ & 2000-2014 \\
\hline Japonia & 3,59 & $1,20 \%$ & $2000-2014$ & 2,79 & $1,95 \%$ & 2000-2014 \\
\hline Korea Południowa & 4,29 & $4,62 \%$ & $2000-2014$ & 3,36 & $5,40 \%$ & 2000-2014 \\
\hline Litwa & 1,01 & $2,32 \%$ & 2003-2014 & 0,30 & $6,49 \%$ & 2004-2014 \\
\hline Łotwa & 0,69 & $2,89 \%$ & $2000-2014$ & 0,24 & $2,08 \%$ & 2000-2014 \\
\hline Meksyk & 0,54 & $3,34 \%$ & $2000-2014$ & 0,17 & $4,94 \%$ & 2001-2011 \\
\hline Niemcy & 2,90 & $1,30 \%$ & $2000-2014$ & 1,95 & $1,07 \%$ & 2000-2014 \\
\hline Norwegia & 1,71 & $0,66 \%$ & 2001-2014 & 0,92 & $-0,08 \%$ & 2001-2014 \\
\hline Polska & 0,94 & $2,60 \%$ & $2000-2014$ & 0,44 & $4,74 \%$ & 2000-2014 \\
\hline Portugalia & 1,29 & $3,96 \%$ & $2000-2014$ & 0,60 & $8,16 \%$ & 2000-2014 \\
\hline Rosja & 1,19 & $0,57 \%$ & 2000-2014 & 0,71 & $-0,30 \%$ & 2000-2014 \\
\hline Słowenia & 2,39 & $3,83 \%$ & 2000-2014 & 1,85 & $6,56 \%$ & 2000-2014 \\
\hline Stany Zjednoczone & 2,74 & $0,30 \%$ & $2000-2013$ & 1,94 & $0,00 \%$ & 2000-2013 \\
\hline Szwajcaria & 2,97 & $1,88 \%$ & 2000-2012 & 2,05 & $1,47 \%$ & 2000-2012 \\
\hline Turcja & 1,01 & $5,08 \%$ & $2000-2014$ & 0,50 & $8,48 \%$ & 2000-2014 \\
\hline $\mathrm{UE}(28)$ & 1,95 & $1,00 \%$ & $2000-2014$ & 1,23 & $1,00 \%$ & 2000-2014 \\
\hline Węgry & 1,37 & $3,74 \%$ & $2000-2014$ & 0,98 & $7,63 \%$ & 2000-2014 \\
\hline Wielka Brytania & 1,70 & $-0,08 \%$ & $2000-2014$ & 1,09 & $-0,19 \%$ & 2000-2014 \\
\hline Włochy & 1,29 & $1,64 \%$ & $2000-2014$ & 0,72 & $2,64 \%$ & 2000-2014 \\
\hline
\end{tabular}

* - w kolumnie danych CAGR podano lata, których dotyczy średnioroczny wzrost; brak możliwości ujednolicenia okresu analizy wynika z dostępności danych.

Źródło: opracowanie własne na podstawie danych z bazy: Science, Technology and Innovation Outlook, 2016, OECD (28.07.2017). 
na założyć, że inwestorzy zagraniczni mają dość duży udział w wydatkach na B+R w porównaniu z innymi krajami. Według danych OECD (baza: International Cooperation in Patents) prawie połowa patentów zgłaszanych przez Indie w procedurze PCT jest wynikiem współpracy z nierezydentami. Dla porównania odsetek te w przypadku Chin wynosi 13,8\%, Japonii - 2,3\%, Korei Pd. - 3,8\%, Stanów Zjednoczonych $11,8 \%$, a państw UE - 13,6\%.

\section{Badanie empiryczne}

W wielu przeprowadzonych dotychczas badaniach empirycznych starano się uchwycić wpływ różnych czynników na wzrost eksportu. Poszukiwanie przyczyn wskazanych zmian w geograficznej strukturze eksportu usług opartych na wiedzy stanowiło inspirację do podjęcia badania empirycznego przedstawionego w dalszej części tego artykułu. Podjęta zostanie próba oceny, czy istnieje zależność między tymi czynnikami a eksportem usług opartych na wiedzy. Odpowiedź na to pytanie pozwoli zidentyfikować czynniki wpływające na zwiększenie udziału gospodarki w międzynarodowych sieciach dostaw.

Starając się lepiej uchwycić zależności między badanymi zmiennymi oraz ich znaczenie w kontekście międzynarodowych sieci dostaw, zmienną objaśnianą przedstawiono w dwóch ujęciach: usługi oparte na wiedzy ogółem i usługi biznesowe oparte na wiedzy. Eksport biznesowych usług wiedzochłonnych przyjęto bowiem jako wyraz zaangażowania kraju w międzynarodowe sieci dostaw. Wynik eksportu tych usług dla danego kraju pokazuje, jak ten kraj jest atrakcyjny jako lokalizacja procesów pozaprodukcyjnych podlegających offshoringowi.

Badanie przeprowadzono z użyciem dwóch modeli empirycznych. Pierwszy z nich (model M1) obejmuje dane dotyczące usług, które wg klasyfikacji Eurostatu należą do grupy usług wiedzochłonnych (knowledge-intensive). Drugi natomiast model (M2) zawiera dane o usługach wiedzochłonnych, będących podgrupą pierwszej badanej grupy. W tym modelu wzięto pod uwagę usługi wiedzochłonne, które odnoszą się do współpracy między przedsiębiorstwami. Zestawiając tę podgrupę usług wiedzochłonnych ze wspomnianymi wcześniej klasyfikacjami usług biznesowych, wyraźnie widać, że wyróżnione dla modelu drugiego usługi są to usługi biznesowe. Jednocześnie należy zauważyć, że niektóre spośród wymienionych usług wg klasyfikacji Eurostatu nie zostały uwzględnione w badaniu empirycznym ze względu na brak danych w wykorzystanych bazach statystycznych (zob. tabela 2).

W badaniu wykorzystano tradycyjnie stosowane zmienne kontrolujące, czyli determinanty intensywności eksportu, a mianowicie PKB na mieszkańca i wydajność pracy. Uwzględniono także potencjał kraju do świadczenia usług opartych na wiedzy dzięki zmiennym, takim jak zatrudnienie, koszty pracy i wartość dodana w usługach profesjonalnych naukowych i technicznych. W modelu dodano ponadto zmienną opisującą nakłady na środki trwałe, aby dać wyraz występującym w poszczególnych krajach różnicom w wyposażeniu w czynniki produkcji. 
Tabela 2. Usługi wiedzochłonne w podziale na kategorie wg klasyfikacji Eurostatu wykorzystane w badaniu empirycznym (nazwy w brzmieniu oryginalnym)

\begin{tabular}{|c|c|c|}
\hline Kategorie usług & $\begin{array}{c}\text { Rodzaje usług w danej kategorii } \\
\text { (w nawiasach podano działy PKWiU) }\end{array}$ & $\begin{array}{c}\text { Model } \\
\text { wykorzystujący dane* }\end{array}$ \\
\hline \multirow{9}{*}{$\begin{array}{l}\text { Usługi oparte } \\
\text { na wiedzy } \\
\text { z wyłączeniem } \\
\text { pośrednictwa } \\
\text { finansowego } \\
\text { i usług } \\
\text { zaawansowanych } \\
\text { technicznie }\end{array}$} & Transport wodny (50) & M1 \\
\hline & Transport lotniczy (51) & M1 \\
\hline & Usługi prawne, rachunkowo-księgowe i doradztwa podatkowego (69) & M1, M2 \\
\hline & $\begin{array}{l}\text { Usługi firm centralnych (head offices); usługi doradztwa związane } \\
\text { z zarządzaniem ( } 70)\end{array}$ & M1, M2 \\
\hline & $\begin{array}{l}\text { Usługi architektoniczne i inżynierskie; usługi w zakresie badań } \\
\text { i analiz technicznych (71) }\end{array}$ & M1, M2 \\
\hline & Usługi reklamowe; usługi badania rynku i opinii publicznej (73) & $\mathrm{M} 1, \mathrm{M} 2$ \\
\hline & Pozostała działalność profesjonalna, naukowa i techniczna (74) & M1, M2 \\
\hline & Usługi związane z zatrudnieniem (78) & b.d. \\
\hline & Usługi detektywistyczne i ochroniarskie (80) & b.d. \\
\hline \multirow{6}{*}{$\begin{array}{l}\text { Usługi } \\
\text { zaawansowane } \\
\text { technicznie }\end{array}$} & $\begin{array}{l}\text { Usługi związane z produkcją filmów, nagrań wideo, programów } \\
\text { telewizyjnych, nagrań dźwiękowych i muzycznych (59) }\end{array}$ & b.d. \\
\hline & $\begin{array}{l}\text { Usługi związane z nadawaniem programów ogólnodostępnych } \\
\text { i abonamentowych }(60)\end{array}$ & b.d. \\
\hline & Usługi telekomunikacyjne (61) & M1, M2 \\
\hline & $\begin{array}{l}\text { Usługi związane z oprogramowaniem i doradztwem w zakresie } \\
\text { informatyki i usługi powiązane ( } 62 \text { ) }\end{array}$ & M1, M2 \\
\hline & Usługi w zakresie informacji (63) & M1, M2 \\
\hline & Usługi w zakresie badań naukowych i prac rozwojowych (72) & M1, M2 \\
\hline \multirow[t]{3}{*}{$\begin{array}{l}\text { Finansowe usługi } \\
\text { oparte na wiedzy }\end{array}$} & $\begin{array}{l}\text { Usługi finansowe, z wyłączeniem ubezpieczeń i funduszów } \\
\text { emerytalnych (64) }\end{array}$ & M1 \\
\hline & $\begin{array}{l}\text { Usługi ubezpieczeniowe, reasekuracyjne oraz usługi związane } \\
\text { z funduszami emerytalnymi, z wyłączeniem obowiązkowego } \\
\text { ubezpieczenia społecznego (65) }\end{array}$ & M1 \\
\hline & $\begin{array}{l}\text { Usługi wspomagające usługi finansowe oraz ubezpieczenia } \\
\text { i fundusze emerytalne (66) }\end{array}$ & b.d. \\
\hline \multirow{11}{*}{$\begin{array}{l}\text { Pozostałe usługi } \\
\text { oparte na wiedzy }\end{array}$} & Usługi związane z działalnością wydawniczą (58) & b.d. \\
\hline & Usługi weterynaryjne (75) & b.d. \\
\hline & $\begin{array}{l}\text { Usługi administracji publicznej i obrony narodowej; usługi } \\
\text { w zakresie obowiązkowych zabezpieczeń społecznych (84) }\end{array}$ & M1 \\
\hline & Usługi w zakresie edukacji (85) & M1 \\
\hline & Usługi w zakresie opieki zdrowotnej (86) & M1 \\
\hline & Usługi pomocy społecznej z zakwaterowaniem (87) & b.d. \\
\hline & Usługi pomocy społecznej bez zakwaterowania (88) & b.d. \\
\hline & Usługi kulturalne i rozrywkowe (90) & b.d. \\
\hline & $\begin{array}{l}\text { Usługi bibliotek, archiwów, muzeów oraz pozostałe usługi w zakresie } \\
\text { kultury (91) }\end{array}$ & b.d. \\
\hline & Usługi związane z grami losowymi i zakładami wzajemnymi (92) & b.d. \\
\hline & Usługi związane ze sportem, rozrywką i rekreacją (93) & b.d. \\
\hline
\end{tabular}

* M1 - dane zastosowane w modelu 1, M2 - dane zastosowane w modelu 2, b.d. - brak danych statystycznych w materiałach źródłowych.

Źródło: opracowanie własne na podstawie: http://ec.europa.eu/eurostat/statistics-explained/index.php/ Glossary:Knowledge-intensive_services_(KIS) (21.05.2017). 
W celu zbadania wpływu tzw. czynników technologicznych, w obu modelach przyjęto zestaw występujących w literaturze przedmiotu wskaźników odnoszących się do aktywności badawczej czy inwestycji w badania i rozwój nowych technologii. Badania nad wpływem czynników technologicznych pojawiły się w literaturze jeszcze w latach dziewięćdziesiątych [Wolff 1995; Landesmann-Pfaffermayr 1997].

Ponadto $\mathrm{w}$ przeprowadzonej analizie uwzględniono czynniki bezpośrednio wpływające na rozwój technologii (tj. nakłady na $\mathrm{B}+\mathrm{R}$, pracownicy $\mathrm{B}+\mathrm{R}$ ). Podobne wyniki otrzymali także Aaby i Slater [1989]. W literaturze odnaleźć również można czynniki pośrednie, tj. komponenty o wysokim poziomie technologicznym, dobra inwestycyjne, dzięki którym przedsiębiorstwo poprawić może swój potencjał technologiczny i wprowadzić innowację [Fagerberg 1996; Carlin i in. 2001].

Większość jednak publikacji dotyczy czynników bezpośrednich i te właśnie zastosowano $\mathrm{w}$ przeprowadzonym badaniu.

Tabela 3. Wyjaśnienie i wskaźniki zastosowane do zmiennych objaśniających w badaniu empirycznym

\begin{tabular}{|c|c|c|c|}
\hline $\begin{array}{c}\text { Nazwa } \\
\text { zmiennej } \\
\text { objaśniającej }\end{array}$ & Wskaźnik, jednostka & Jednostka & Wyjaśnienie \\
\hline 1 & 2 & 3 & 4 \\
\hline gdppc & PBB per capita & $\begin{array}{l}\text { USD w cenach stałych } \\
\text { wg parytetu siły } \\
\text { nabywczej }\end{array}$ & PKB na 1 mieszkańca \\
\hline labprod & wydajność pracy & $\begin{array}{l}\text { USD w cenach stałych } \\
\text { wg parytetu siły } \\
\text { nabywczej }\end{array}$ & PKB na godzinę \\
\hline emplnt & zatrudnienie & liczba osób & $\begin{array}{l}\text { liczba zatrudnionych ogółem } \\
\text { w usługach profesjonalnych, } \\
\text { naukowych i technicznych }{ }^{\text {a) }}\end{array}$ \\
\hline labcost & koszty siły roboczej & USD & $\begin{array}{l}\text { wynagrodzenie pracowników } \\
\text { w usługach profesjonalnych, } \\
\text { naukowych i technicznych }{ }^{\text {b) }}\end{array}$ \\
\hline $\mathrm{va}$ & wartość dodana & $\%$ & $\begin{array}{l}\text { udział wartości dodanej w usługach } \\
\text { profesjonalnych, naukowych } \\
\text { i technicznych w wartości dodanej } \\
\text { ogółem }\end{array}$ \\
\hline gfcfgdp & $\begin{array}{l}\text { GFCF - gross fixed } \\
\text { capital formation; } \\
\text { nakłady brutto na } \\
\text { środki trwałe jako \% } \\
\text { PKB }\end{array}$ & $\%$ & $\begin{array}{l}\text { udział w PKB wydatków na } \\
\text { nabycie, w tym zakup nowych } \\
\text { lub używanych aktywów, } \\
\text { i tworzenie aktywów przez innych } \\
\text { producentów na potrzeby danego } \\
\text { przedsiębiorstwa }\end{array}$ \\
\hline
\end{tabular}




\begin{tabular}{|c|c|c|c|}
\hline 1 & 2 & 3 & 4 \\
\hline gerd & $\begin{array}{l}\mathrm{GERD}-\text { gross } \\
\text { domestic expenditure } \\
\text { on } R \& D ; \text { wydatki na } \\
\mathrm{B}+\mathrm{R} \text { ogółem }\end{array}$ & $\begin{array}{l}\text { USD w cenach stałych } \\
\text { wg parytetu siły } \\
\text { nabywczej }\end{array}$ & $\begin{array}{l}\text { wydatki na badania i rozwój } \\
\text { przedsiębiorstw, instytucji } \\
\text { szkolnictwa wyższego, a także } \\
\text { organizacji rządowych i prywatnych } \\
\text { organizacji non profit }\end{array}$ \\
\hline gbaord & $\begin{array}{l}\text { GBAORD - } \\
\text { government budget } \\
\text { appropriations or } \\
\text { outlays for research } \\
\text { and development }\end{array}$ & $\begin{array}{l}\text { USD w cenach stałych } \\
\text { wg parytetu siły } \\
\text { nabywczej }\end{array}$ & $\begin{array}{l}\text { wydatki na } B+R \text { przyznawane } \\
\mathrm{z} \text { centralnych lub regionalnych } \\
\text { budżetów; nie uwzględniają } \\
\text { funduszy samorządu terytorialnego }\end{array}$ \\
\hline gerdabr & $\begin{array}{l}\text { gross domestic } \\
\text { expenditure on } R \& D \\
\text { financed by abroad }\end{array}$ & $\begin{array}{l}\text { USD w cenach stałych } \\
\text { wg parytetu siły } \\
\text { nabywczej }\end{array}$ & $\begin{array}{l}\text { wydatki na badania i rozwój } \\
\text { przedsiębiorstw, instytucji } \\
\text { szkolnictwa wyższego, a także } \\
\text { organizacji rządowych i prywatnych } \\
\text { organizacji non profit. Źródłem tych } \\
\text { wydatków są podmioty zagraniczne }\end{array}$ \\
\hline rschers & $\begin{array}{l}\text { pracownicy } \\
\text { naukowo-badawczy }\end{array}$ & $\begin{array}{l}\text { FTE - full time } \\
\text { equivalent; jednostki } \\
\text { przeliczeniowe } \\
\text { służące do ustalania } \\
\text { faktycznego } \\
\text { zatrudnienia } \\
\text { w działalności B+R. } \\
\text { Jeden ekwiwalent } \\
\text { pełnego czasu } \\
\text { pracy (w skrócie } \\
\text { EPC) oznacza jeden } \\
\text { osoborok poświęcony } \\
\text { wyłącznie na } \\
\text { działalność } \mathrm{B}+\mathrm{R}^{\mathrm{c}} \text { ) }\end{array}$ & $\begin{array}{l}\text { pracownicy naukowo-badawczy są } \\
\text { to specjaliści zajmujący się pracą } \\
\text { koncepcyjną i tworzeniem nowej } \\
\text { wiedzy, wyrobów, usług, procesów, } \\
\text { metod i systemów, a także } \\
\text { kierowaniem (zarządzaniem) } \\
\text { projektami badawczymi, } \\
\text { związanymi z realizacją tych }_{\text {zadañd) }^{\text {d) }}}\end{array}$ \\
\hline
\end{tabular}

a) Sekcja Mwg Polskiej Klasyfikacji Działalności PKD 2007 oraz klasyfikacji działalności NACE Rev. 2; b) Jak wyżej; c) Zatrudnienie w działalności B+R w ekwiwalentach pełnego czasu pracy ustala się na podstawie proporcji czasu przepracowanego przez poszczególnych pracowników w ciągu roku sprawozdawczego przy pracach $\mathrm{B}+\mathrm{R}$ w stosunku do pełnego czasu pracy obowiązującego w danej instytucji na danym stanowisku pracy. Więcej zob. [GUS, b.d.]; d) Na podstawie [GUS, b.d.].

Źródło: opracowanie własne.

Oszacowanie specyfikacji modelu M1 oraz modelu M2 przeprowadzono przy użyciu pakietu ekonometrycznego STATA11.

Analizę przeprowadzono dla eksportu usług 28 krajów ${ }^{4}$ w okresie 2004-2013 $\mathrm{z}$ wykorzystaniem danych statystycznych z bazy OECD oraz Eurostatu. Wyniki estymacji przedstawiają tabele 4 i 5 .

${ }^{4}$ Austria, Belgia, Czechy, Dania, Estonia, Finlandia, Francja, Grecja, Hiszpania, Holandia, Irlandia, Islandia, Japonia, Litwa, Luksemburg, Niemcy, Norwegia, Polska, Portugalia, Rumunia, Słowacja, Słowenia, Stany Zjednoczone, Szwecja, Turcja, Węgry, Wielka Brytania, Włochy. 
Tabela 4. Wyniki estymacji modelu empirycznego dla eksportu usług wiedzochłonnych ogółem (model M1)

\begin{tabular}{|c|c|c|c|c|c|}
\hline & $(1)$ & $(2)$ & (3) & $(4)$ & $(5)$ \\
\hline & leksportkis1 & leksportkis 1 & leksportkis 1 & leksportkis 1 & leksportkis 1 \\
\hline \multirow[t]{2}{*}{$\lg d p p c$} & $2,214^{* * *}$ & $4,071^{* * *}$ & $4,335^{* * *}$ & $4,447^{* * *}$ & $4,444^{* * *}$ \\
\hline & $(3,62)$ & $(11,33)$ & $(11,67)$ & $(11,60)$ & $(12,25)$ \\
\hline \multirow[t]{2}{*}{ llabprod } & $-0,0514$ & $-2,622^{* * *}$ & $-2,854^{* * *}$ & $-2,938^{* * *}$ & $-2,801^{* * *}$ \\
\hline & $(-0,07)$ & $(-6,84)$ & $(-6,90)$ & $(-7,41)$ & $(-7,41)$ \\
\hline \multirow[t]{2}{*}{ lemplnt } & $0,545^{* * *}$ & $0,455^{* * *}$ & $0,488^{* * *}$ & $0,538^{* * *}$ & $0,466^{* * *}$ \\
\hline & $(3,47)$ & $(4,80)$ & $(7,09)$ & $(6,99)$ & $(4,43)$ \\
\hline \multirow[t]{2}{*}{ llabcost } & 0,100 & 0,0652 & $0,0998^{*}$ & $0,0852^{*}$ & 0,0342 \\
\hline & $(0,86)$ & $(1,52)$ & $(2,51)$ & $(2,02)$ & $(0,82)$ \\
\hline \multirow[t]{2}{*}{$l v a$} & $1,583^{*}$ & $1,552^{* * *}$ & $1,704^{* * *}$ & $1,471^{* * *}$ & $1,470^{* * *}$ \\
\hline & $(2,39)$ & $(7,21)$ & $(7,80)$ & $(6,43)$ & $(6,61)$ \\
\hline \multirow[t]{2}{*}{$\lg f c f g d p$} & $-0,602^{*}$ & $-1,213^{* * *}$ & $-1,284^{* * *}$ & $-0,856^{* *}$ & $-1,183^{* * *}$ \\
\hline & $(-2,43)$ & $(-4,38)$ & $(-4,51)$ & $(-3,25)$ & $(-4,36)$ \\
\hline \multirow[t]{2}{*}{ lgerd } & & 0,147 & & & \\
\hline & & $(1,58)$ & & & \\
\hline \multirow[t]{2}{*}{ lgbaord } & & & $0,113^{*}$ & & \\
\hline & & & $(2,38)$ & & \\
\hline \multirow[t]{2}{*}{ lgerdabr } & & & & $0,143^{*}$ & \\
\hline & & & & $(2,07)$ & \\
\hline \multirow[t]{2}{*}{ lrschers } & & & & & 0,199 \\
\hline & & & & & $(1,80)$ \\
\hline \multirow[t]{2}{*}{ _cons } & $-19,43^{* * *}$ & $-27,60^{* * *}$ & $-29,41^{* * *}$ & $-31,48^{* * *}$ & $-31,31^{* * *}$ \\
\hline & $(-5,29)$ & $(-9,74)$ & $(-10,37)$ & $(-10,27)$ & $(-10,23)$ \\
\hline$N$ & 187 & 187 & 180 & 158 & 183 \\
\hline $\begin{array}{l}R^{2} \text { within } \\
R^{2} \text { between } \\
R^{2} \text { overall }\end{array}$ & $\begin{array}{l}0,5023 \\
0,8775 \\
0,8581 \\
\end{array}$ & & & & \\
\hline
\end{tabular}

W nawiasach podano wartości statystyk $t$-studenta; ${ }^{*} p<0,05,{ }^{* *} p<0,01,{ }^{* * *} p<0,001$.

Źródło: opracowanie własne.

Uzyskane wyniki estymacji testowano odpowiednimi testami statystycznymi w celu ustalenia charakteru efektów (stałe lub zmienne). Po przeprowadzeniu testu Hausmana model M1 charakteryzują efekty losowe, zaś model M2 - efekty stałe w przypadku podstawowej wersji modelu. Występowanie efektów losowych wynika prawdopodobnie ze zbyt dużej agregacji danych dotyczących usług KIS ogółem. Oszacowanie modeli rozszerzonych w ujęciu M1 przeprowadzono metodą FGLS, której wynik nie przedstawił wartości współczynnika dopasowania $\mathrm{R}^{2}$. 
Charakter danych i ich zmienność w czasie sugerowałyby występowanie efektów stałych i tego właśnie dowiódł test Hausmana w modelu M2.

Model M2 poddano dalszej weryfikacji, sprawdzając jego heteroskedastyczność (test Walda) oraz korelację seryjną (test Wooldridga). W wyniku przeprowadzonych testów oszacowanie podstawowej wersji modelu przeprowadzono z użyciem modelu regresji liniowej.

Tabela 5. Wyniki estymacji modelu empirycznego dla eksportu wybranych usług wiedzochłonnych (model M2)

\begin{tabular}{|c|c|c|c|c|c|}
\hline & (1) & $(2)$ & (3) & (4) & $(5)$ \\
\hline & leksportkis2 & leksportkis 2 & leksportkis 2 & leksportkis2 & leksportkis 2 \\
\hline \multirow[t]{2}{*}{$\lg d p p c$} & $-2,299$ & $2,220^{* * *}$ & $2,675^{* * *}$ & $2,872^{* * *}$ & $2,695^{* * *}$ \\
\hline & $(-1,40)$ & $(5,35)$ & $(6,21)$ & $(6,01)$ & $(6,22)$ \\
\hline \multirow[t]{2}{*}{ llabprod } & $5,950^{* *}$ & $-1,363^{* *}$ & $-1,715^{* * *}$ & $-1,975^{* * *}$ & $-1,482^{* *}$ \\
\hline & $(3,18)$ & $(-3,07)$ & $(-3,57)$ & $(-4,01)$ & $(-3,28)$ \\
\hline \multirow[t]{2}{*}{ lemplnt } & 0,212 & 0,192 & $0,309^{* * *}$ & $0,302^{* *}$ & $0,253^{*}$ \\
\hline & $(0,21)$ & $(1,74)$ & $(3,82)$ & $(3,12)$ & $(2,02)$ \\
\hline \multirow[t]{2}{*}{ llabcost } & 1,012 & $0,123^{*}$ & $0,205^{* * *}$ & $0,110^{*}$ & $0,119^{*}$ \\
\hline & $(1,95)$ & $(2,46)$ & $(4,40)$ & $(2,08)$ & $(2,37)$ \\
\hline \multirow[t]{2}{*}{ lva } & 1,262 & $1,158^{* * *}$ & $1,397^{* * *}$ & $1,010^{* * *}$ & $1,208^{* * *}$ \\
\hline & $(1,46)$ & $(4,60)$ & $(5,45)$ & $(3,51)$ & $(4,50)$ \\
\hline \multirow[t]{2}{*}{$\lg f c f g d p$} & 1,113 & $-0,877^{* *}$ & $-1,001^{* *}$ & $-0,384$ & $-0,776^{*}$ \\
\hline & $(1,85)$ & $(-2,68)$ & $(-2,97)$ & $(-1,14)$ & $(-2,34)$ \\
\hline \multirow[t]{2}{*}{ lgerd } & & $0,345^{* *}$ & & & \\
\hline & & $(3,22)$ & & & \\
\hline \multirow[t]{2}{*}{ lgbaord } & & & $0,206^{* * *}$ & & \\
\hline & & & $(3,74)$ & & \\
\hline \multirow[t]{2}{*}{ lgerdabr } & & & & $0,381^{* * *}$ & \\
\hline & & & & $(4,43)$ & \\
\hline \multirow[t]{2}{*}{ lrschers } & & & & & $0,328^{*}$ \\
\hline & & & & & $(2,49)$ \\
\hline \multirow[t]{2}{*}{ _cons } & $-7,001$ & $-14,53^{* * *}$ & $-17,58^{* * *}$ & $-20,08^{* * *}$ & $-20,20^{* * *}$ \\
\hline & $(-0,77)$ & $(-4,41)$ & $(-5,31)$ & $(-5,22)$ & $(-5,50)$ \\
\hline$N$ & 185 & 185 & 178 & 157 & 181 \\
\hline $\begin{array}{l}R^{2} \text { within } \\
R^{2} \text { between } \\
R^{2} \text { overall }\end{array}$ & $\begin{array}{l}0,7804 \\
0,6691 \\
0,7689\end{array}$ & $\begin{array}{l}0,4686 \\
0,7533 \\
0,7053\end{array}$ & $\begin{array}{l}0,5207 \\
0,8089 \\
0,7583\end{array}$ & $\begin{array}{l}0,4805 \\
0,6617 \\
0,6218\end{array}$ & $\begin{array}{l}0,4773 \\
0,7559 \\
0,6977 \\
\end{array}$ \\
\hline
\end{tabular}

W nawiasach podano wartości statystyk $t$-studenta; ${ }^{*} p<0,05,{ }^{* *} p<0,01,{ }^{* * *} p<0,001$.

Źródło: opracowanie własne w programie STATA11. 
W analizowanych rozszerzonych wersjach modelu M1 istotność statystyczną ustalono w przypadku zmiennych gbaord oraz gerbabr. Publiczne wydatki na $\mathrm{B}+\mathrm{R}$ z budżetów centralnych i regionalnych okazały się mieć pozytywny wpływ na eksport usług opartych na wiedzy ogółem przy poziomie istotności $5 \%$. Podobnie jak wydatki na $\mathrm{B}+\mathrm{R}$ ze źródeł zagranicznych. W badaniu nie stwierdzono istotności wpływu pozostałych zmiennych specyficznych na eksport usług opartych na wiedzy ogółem (zob. tabela 4).

Nieco odmienne wyniki od estymacji modelu M1 uzyskano w przypadku oszacowań w modelu M2, który obejmuje eksport węższej grupy usług. W tym ujęciu skoncentrowano się na usługach wiedzochłonnych, będących przedmiotem współpracy między przedsiębiorstwami.

Jak wskazują wyniki przedstawione w tabeli 5, większość analizowanych wersji modelu M2 szacuje parametry czynników wpływających na eksport w sposób zgodny z przewidywaniami. Warto jednak zauważyć interesujący wynik estymacji w przypadku wpływu wydajności pracy na eksport. Okazuje się bowiem, że wbrew dotychczas przyjętej doktrynie, że wydajność sprzyja eksportowi, co udało się wielokrotnie udowodnić, badając eksport dóbr [Clerides i in.1998; Bernard, Jensen 1999; Baldwin, Gu 2003, 2004; Wagner 2007; Kasahara, Lapham 2013], w przeprowadzonym badaniu zaobserwowano odwrotną zależność. Negatywny wpływ wydajności pracy na eksport biznesowych usług wiedzochłonnych można wyjaśnić faktem, iż choć ciągle kraje wysoko wydajne, takie jak Stany Zjednoczone, Niemcy czy Wielka Brytania, są ważnymi na świecie eksporterami usług wiedzochłonnych, to w przypadku usług biznesowych rośnie znaczenie krajów, które charakteryzuje znacznie niższa wydajność pracy (jak Chiny, Indie, kraje Europy Środkowej i Wschodniej). Ujemna zależność pomiędzy wydajnością a eksportem występować więc będzie wszędzie tam, gdzie istnieją powiązania gospodarcze wynikające $\mathrm{z}$ offshoringu procesów wiedzochłonnych. Kraje o wysokiej wydajności będą w tym przypadku importerami, a eksporterami kraje charakteryzujące się niską wydajnością. Należy przy tym pamiętać, że miernikiem wydajności, o której mowa, jest PKB na godzinę w ujęciu ogólnogospodarczym, bez uwzględnienia produkcji czy usług. Podobną interpretację należy przyjąć w przypadku negatywnego wpływu inwestycji w środki trwałe na eksport wykazanego w większości wyników estymacji modelu M2.

Istotność statystyczną wykazano w przypadku wszystkich zmiennych specyficznych. Spośród nich największy wpływ na eksport biznesowych usług wiedzochłonnych mają inwestycje w B+R ze źródeł zagranicznych, choć porównywalna zależność występuje także w przypadku inwestycji w $\mathrm{B}+\mathrm{R}$ ze środków krajowych. Niewiele mniejszy wpływ na eksport ma liczba zatrudnionych pracowników naukowo-badawczych, lecz wpływ tego czynnika okazał się istotny statystycznie na poziomie 5\%. Najsłabiej na eksport analizowanej grupy usług oddziałują wydatki publiczne z funduszy centralnych i regionalnych. 


\section{Zakończenie}

Poszukując przyczyn zmian, jakie zaszły w ostatnim czasie w geograficznej strukturze eksportu usług opartych na wiedzy, nie sposób nie zauważyć wpływu przeobrażania się strategii przedsiębiorstw w zakresie offshoringu. Umiędzynarodowienie łańcucha wartości, które tradycyjnie dotyczyło procesów produkcyjnych w ostatnich latach coraz częściej odnoszono również do procesów pozaprodukcyjnych. Trudności $\mathrm{w}$ organizacji procesów w ramach macierzystej struktury i lokalizacji zaczęto odczuwać nie tylko w odniesieniu do procesów księgowych czy administracyjnych. Coraz częściej firmy odczuwają trudności w znalezieniu pracowników wysoko wykwalifikowanych do procesów wiedzochłonnych, jak prace $B+R$, inżynieryjne, projektowe czy informatyczne. Efektem tego jest dokonywanie offshoringu tych procesów, co widać wyraźnie w statystykach handlu usługami.

Analiza eksportu usług w podziale na dwie grupy: usługi oparte na wiedzy oraz biznesowe usługi oparte na wiedzy, prowadzi do interesujących wniosków w kontekście czynników sprzyjających poprawie atrakcyjności danej gospodarki jako miejsca lokalizacji procesów wiedzochłonnych w ramach offshoringu.

Na podstawie wyników przeprowadzonego badania empirycznego ustalono, że na eksport usług wiedzochłonnych ogółem pozytywny wpływ ma wzrost wydatków publicznych na $\mathrm{B}+\mathrm{R}$ z budżetów centralnych i regionalnych oraz ze źródeł zagranicznych. Natomiast jeśli chodzi o grupę usług charakterystycznych dla współpracy przedsiębiorstw w ramach offshoringu, wraz we wzrostem wydatków ze wspomnianych źródeł intensywność eksportu wzrasta jeszcze mocniej. Na eksport biznesowych usług opartych na wiedzy wpływ mają również liczba zatrudnionych pracowników naukowo-badawczych oraz wydatki na B+R ogółem. Jednocześnie okazało się, że poprawa wydajności pracy oraz zwiększenie inwestycji w środki trwałe ujemnie wpływają na eksport analizowanej grupy usług.

Podsumowując, należy podkreślić, iż dążenie do poprawy atrakcyjności danej gospodarki jako miejsca lokalizacji procesów wiedzochłonnych w ramach offshoringu powinno wiązać się ze zwiększeniem wydatków na prace $\mathrm{B}+\mathrm{R}$ oraz z działaniami przyczyniającym się do wzrostu liczby pracowników naukowo-badawczych w danym kraju.

\section{Literatura}

Aaby N.E., Slater S.F., 1989, Managerial influences on export performance: a review of the empirical literature 1978-88, International Marketing Review, vol. 6, no. 4, s. 53-68.

Baldwin J.R., Gu W., 2003, Export-market participation and productivity performance in Canadian manufacturing, Canadian Journal of Economics, vol. 36, issue 3, s. 634-657.

Baldwin J.R., Gu W., 2004, Trade liberalization: export-market participation, productivity growth and innovation, Oxford Review of Economic Policy, vol. 20, issue 3, s. 372-392. 
Bernard A.B., Jensen J.B., 1999, Exceptional exporter performance: cause, effect or both?, Journal of International Economics, 47, s. 1-25.

Bettencourt L.A., Ostrom A.L., Brown S.W., Roundtree R.I., 2002, Client co-production in knowledge-intensive business services, California Management Review, vol. 44, s. 100-128.

Budnikowski A., 2017, Ekonomia międzynarodowa, Polskie Wydawnictwo Ekonomiczne, Warszawa.

Campa J., Goldberg L.S., 1997, The Evolving External Orientation of Manufacturing Industries: Evidence from Four Countries, NBER Working Papers, No. 5919, National Bureau of Economic Research.

Carlin W., Glyn A., van Reenen J., 2001, Export market performance of OECD countries: An empirical examination of the role of cost competitiveness, The Economic Journal, vol. 111, iss. 468, s. 128-162.

Cavusgil S.T., 1984, Differences among exporting firms based on their degree of internationalization, Journal of Business Research, vol. 12, no. 3, s. 195-208.

Cavusgil S.T., Zou S., 1994, Marketing strategy-performance relationship: an investigation of the empirical link in export market ventures, Journal of Marketing, vol. 58, s. 1-21.

Ceglowski J., 2006, Does gravity matter in a service economy? Review of World Economics, vol. 142, iss. 2.

Chilimoniuk-Przeździecka E., 2011, Eksport ustug biznesowych z Polski, Zeszyty Naukowe Uniwersytetu Ekonomicznego w Poznaniu, nr 179, s. 45-56.

Chilimoniuk-Przeździecka, 2016, Globalne przeplywy ustug badawczo-rozwojowych-przyczyny i kierunki, International Business and Global Economy, nr 35/1, s. 279-294.

Chilimoniuk-Przeździecka E., Kuźnar A., 2016, Znaczenie usług $w$ globalnych tańcuchach wartości, Gospodarka Narodowa, nr 5(285), s. 141-156.

Clerides S.K., Lach S., Tybout J.R., 1998, Is learning by exporting important? Micro-dynamic evidence from Colombia, Mexico, and Morocco, Quarterly Journal of Economics, vol. 113, s. 903948.

Den Hertog P., 2000, Knowledge-intensive business services as co-producers of innovation, International Journal of Innovation Management, vol. 4, no. 4, s. 491-528.

Den Hertog P., Bilderbeek R., Maltha S., 1997, Intangibles: The Soft Side of Innovation, Futures, vol. 29 , no. 1 , s. $33-45$.

Dominguez L.V., Sequeira C.G., 1993, Determinants of LDC exporters'performance: a cross-national study, Journal of International Business Studies, vol. 24, s. 19-40.

Fagerberg J., 1996, Technology and Competitiveness, Working Papers, No. 1996548, Archives from Centre for Technology, Innovation and Culture, University of Oslo.

François J., Woerz J., 2008, Producer services, manufacturing linkages, and trade, Journal of Industry, Competition and Trade, no. 8, iss. 3-4, s. 199-229.

Gray R., Owen D., Sopher M.J., 1998, Setting up a control system for your organization, Nonprofit World, vol. 16, no. 3, s. 65-76.

Grünfeld L.A., Moxnes A., 2003, The Intangible Globalization: Explaining the Patterns of International Trade in Services, Discussion Paper, No. 657, Norwegian Institute of International Affairs, Oslo.

GUS, 2016, http://stat.gov.pl/obszary-tematyczne/ceny-handel/handel/uslugi-biznesowe, 16,1.html (7.04.2017).

GUS, b.d., Definicje pojęć z zakresu statystyki nauki i techniki, http://stat.gov.p1/metainformacje/slownik-pojec/pojecia-stosowane-w-statystyce-publicznej/760,pojecie.html (7.04.2017).

IMF, 2009, Balance of Payments and International Investment Position Manual (BPM6), International Monetary Fund (IMF).

Kasahara H., Lapham B., 2013, Productivity and the decision to import and export: Theory and evidence, Journal of International Economics, vol. 89, issue 2, s. 297-316.

Kimura F., Lee H., 2006, The Gravity Equation in International Trade in Services, Review of World Economics, vol. 142, iss. 1.

Kuemmerle W., 1999, The drivers of foreign direct investment into research and development: An empirical investigation, Journal of International Business Studies, vol. 30, iss. 1, s. 1-24. 
Kuźnar A., 2007, Ustugi w handlu międzynarodowym, Wydawnictwo Adam Marszałek, Warszawa.

Kuźnar A., 2017, Międzynarodowy handel produktami wiedzy, Oficyna Wydawnicza SGH, Warszawa. Landesmann M., Pfaffermayr M., 1997, Technological competition and trade performance, Applied Economics, vol. 29, iss. 2, s. 179-196.

Lewin A.Y., Zhong X., 2012, Co-evolution of Global Sourcing of Business Support Functions and the Economic Development of Emerging Economies, [w:] Witt M., Redding G. (eds.), Oxford Handbook of Asia Business Systems, Oxford University Press, Oxford.

Manning S., Lewin A.Y., Schuerch M., 2011, The Stability of Offshore Outsourcing Relationships. The Role of Relation Specificity and Client Control, Management International Review, vol. 51, iss. 3 , s. 381-406.

Miles I., Kastrinos N., Flanagan K., Bilderbeek R., den Hertog P., Huntink W., Bouman M., 1995, Knowledge Intensive Business Services: Their Roles and Users, Carriers and Sources of Innovation, PREST, Manchester.

Mirza D., Nicoletti G., 2004, What Is So Special about Trade in Services?, GEP Research Paper, No. 02, Leverhulme Center for Research on Globalization and Economic Policy, Nottingham.

Toivonen M., 2006, Future prospects of knowledge-intensive business services (KIBS) and implications to regional economies, ICFAI Journal of Knowledge Management, vol. 4, no. 3.

USITC, 2013, The Economic Effects of Significant U.S. Import Restraints, Eight Update, USITC Publication 4440, Washington.

Vandermerwe S., Rada J., 1989, Servitization of business: Adding value by adding services, European Management Journal, vol. 6, no. 4.

Wagner J., 2007, Export and productivity: a survey of the evidence from firm-level data, World Economy, vol. 30, iss. 1, s. 60-82.

Walsh K., 2006, Trade in services: does gravity hold? A gravity model approach to estimating barriers to services trade, The Institute for International Integration Studies, Discussion Paper Series, No. 183, IIIS, Dublin.

Walters P.G.P., Samiee S., 1990, A model for assessing performance in small US exporting firms, Entrepreneurship Theory and Practice, Winter, s. 33-50.

Wolff E.N., 1995, Technology and the demand for skills, Levy Economics Institute Working Paper, No. 153.

Wolfmayr Y., 2008, Producer services and competitiveness of manufacturing exports, FIW Research Reports Series I-009.

Wood P., 2002, Knowledge-intensive services and urban innovativeness, Urban Studies, vol. 39, s. $993-1002$. 